Christopher ноокwAY, The Pragmatic Maxim: Essays on Peirce and Pragmatism

Oxford, Oxford University Press, 2012

\title{
Gabriele Gava
}

\section{(2) OpenEdition}

Journals

Electronic version

URL: http://journals.openedition.org/ejpap/563

DOI: 10.4000/ejpap.563

ISSN: 2036-4091

Publisher

Associazione Pragma

\section{Electronic reference}

Gabriele Gava, «Christopher ноокway, The Pragmatic Maxim: Essays on Peirce and Pragmatism », European Journal of Pragmatism and American Philosophy [Online], V-2 | 2013, Online since 24 December 2013, connection on 24 September 2020. URL : http://journals.openedition.org/ejpap/563 ; DOI : https://doi.org/10.4000/ejpap.563

This text was automatically generated on 24 September 2020.

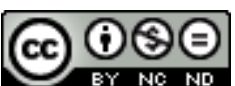

Author retains copyright and grants the European Journal of Pragmatism and American Philosophy right of first publication with the work simultaneously licensed under a Creative Commons AttributionNonCommercial-NoDerivatives 4.0 International License. 


\title{
Christopher Hookway, The Pragmatic Maxim: Essays on Peirce and Pragmatism
}

Oxford, Oxford University Press, 2012

\author{
Gabriele Gava
}

\section{REFERENCES}

Christopher Hookway, The Pragmatic Maxim: Essays on Peirce and Pragmatism, Oxford, Oxford University Press, 2012

Christopher Hookway is, beyond question, one of the most respected scholars working on Peirce and the tradition of pragmatism. His books Peirce (Routledge, 1985) and Truth, Rationality, and Pragmatism (Oxford University Press, 2000) are essential readings for any scholar with an interest on Peirce and pragmatism. Hookway has shown how Peirce has still a lot to contribute to contemporary debates in logic, epistemology, the philosophy of language, etc. The present book, which collects 9 essays published over the last 15 years and 2 original essays, preceded by a useful introduction, is certainly a confirmation of the importance of Hookway's scholarship. Even though each of the essays contained in the collection would deserve a detailed discussion, the book touches on a multiplicity of themes (e.g. Peirce's reactions to skepticism, his account of concepts like truth, reality and inquiry, his various formulations and defenses of the pragmatic maxim, his philosophy of mathematics, his criticism of psychologism, his relationship with other pragmatists, his account of abduction and of the role of imagination in knowledge and perception, etc.), which would be impossible to discuss in a single review. Accordingly, I will single out three themes that run through the essays, which I find relevant for the current research on Peirce and pragmatism. These themes are: Peirce's account of truth and reality and the relationship between these concepts and the aim of inquiry; Peirce's formulations of the pragmatic maxim and the 
various ways in which he attempted to defend it; the relationship between Peirce's philosophy and the positions of other pragmatists (James, Dewey, Lewis, Rorty) and philosophers (Kant).

In his paper "How to Make our Ideas Clear" Peirce famously defined truth as the final opinion held by the community of investigators and reality as the object represented in that opinion. Peirce's account of truth and reality has been the focus of much discussion within and outside Peirce studies. In chapter 2 and 3, Hookway discusses in a subtle way various problems that have been attributed to Peirce's position. He is thus able to present Peirce's views avoiding common simplifications and misunderstandings and to show how his account of truth can constitute a viable option from the standpoint of contemporary philosophy.

3 In chapter 3 ("Truth, Reality, and Convergence"), Hookway shows how the charge that Peirce's account of truth is committed to an absolute conception of reality is mistaken. This charge was advanced by Hilary Putnam, who, following Bernard Williams, describes the absolute conception of reality as a view of the world as it is there independently of specific features of our cognitive apparatus. This account of reality thus omits secondary qualities, values, and artifacts. Putnam stresses that Peirce was committed to such a conception of reality insofar as he claimed that the truth of the final opinion is fated no matter what rational being (humans or other rational beings) inquires into it (54-5). Hookway shows that there are various reasons for rejecting this interpretation. He first makes clear that even those passages, written before 1880, which seem to commit Peirce to an absolute conception of reality could well agree with a rejection of such a conception. Peirce's passages from these years can be read as stressing that "if a proposition is true, then anyone who investigates some question to which that proposition provides the answer is fated to believe it" and not that if a proposition is true, then any inquirer is fated to believe it (56). This interpretation of Peirce's definition of truth "is compatible with rejection of the absolute conception of reality, for it is compatible with the view that our different perspectives are reflected in the varying ranges of questions that we can understand or take seriously" (57). However, if Peirce's adherence to the absolute conception of reality before 1880 cannot be excluded once and for all, Hookway argues that it is possible to do so if we take into consideration Peirce's later writings. For example, around and after 1900 Peirce describes his conception of truth as the final opinion as a hope (59-60) and he accounts for secondary qualities and artifacts as real (61-2). Peirce could not sustain these claims if he endorsed the absolute conception of reality. Hookway then shows how, after 1880, Peirce's conception of reality evolves and it is not defined by means of the concept of truth any more (62-7). This is due to the fact that Peirce developed a new account of indexicality which allowed him to stress that "external things and law governed changes are object of 'immediate' experience" (67). If the concept of truth and reality are not inescapably linked any more, there is no sense in arguing that Peirce's definition of truth commits him to the absolute conception of reality. Hookway concludes the chapter by arguing that Peirce's writings on truth do not constitute a "general theory of truth". Peirce does not want to give an account of what it means for a proposition to be true. Rather, "his pragmatic clarifications of concepts and propositions are best seen as accounts of the (experiential) commitments we incur when we assert or judge the proposition in question" (69). This is a further element to reject Putnam's interpretation. 
In chapter 2 ("Fallibilism and the Aim of Inquiry"), Hookway addresses some arguments that challenge the common assumption that truth is the aim of inquiry. In particular, he analyses how this view has been attacked by Rorty and Davidson, thanks to a pragmatist argument based on fallibilism. This argument stresses that if we endorse fallibilism we cannot claim that truth is the aim of inquiry, insofar as falliblism maintains that we cannot ever know for sure that we have found the truth, then there is no sense in stressing that we should aim to find something that we cannot recognize to possess (41-5). Hookway first notices how fallibilism can be understood as simply stressing that we cannot have "absolute certainty" or a "metaphysical guarantee" that a particular belief is infallibly true (45-6). If we endorse such a characterization of fallibilism "then a commitment to fallibilism is compatible with great confidence and certainty in the adequacy of most of our opinions and methods" (47). Hookway then uses Peirce's account of inquiry and truth to find a way to reconcile fallibilism with our aiming at truth. After noticing how Peirce identifies settled belief, and not truth, as the aim of inquiry (48-9), Hookway shows how Peirce's clarification of the concept of truth as the final opinion is compatible with fallibilism. Peirce's statements on truth "are fallible claims about what we commit ourselves to when we take something to be true, or when we inquire into the truth of something" (50). Peirce's pragmatic clarification of truth is not an identification of the necessary and sufficient conditions for recognizing true statements. Rather, it explains what I commit myself to, when I stress that a proposition is true (50-1). Understanding truth this way gives us the means to recognize how it can have a normative role and it can function as an aim of inquiry, even though we endorse fallibilism (51-2).

5 In the last three chapters of the book, Hookway presents what is without doubt one of the most detailed and thorough analysis of Peirce's pragmatic maxim and of the arguments he advanced in its defense. Chapter 9 reconstructs and clarifies the various formulations of the maxim over the years in relation to the examples Peirce provided. Chapter 10 investigates the relationship between Peirce's and James pragmatism, while chapter 11 analyses in depth the various strategies used by Peirce to defend the maxim of pragmatism. For now, I will focus on chapter 9 and 11.

Chapter 9 ("The Principles of Pragmatism: Peirce's Formulations and Examples") takes into account some ambiguities in Peirce's formulations and examples of the pragmatic maxim. Peirce's original exposition of the pragmatic maxim in "How to Make our Ideas Clear" is famously unclear. This lack of clarity is not removed if we compare this formulation with others, like for example those given in the "Lectures on Pragmatism" delivered at Harvard in 1903, or in other papers on pragmatism written after 1905. Accordingly, it is not easy to identify what is the exact content of the maxim. In particular, Hookway focuses on a crucial ambiguity between what he calls the "pragmatist" and the "verificationist" dimensions of the maxim (167 ff.). The pragmatist dimension of the maxim aims to make explicit those aspects of a conception which identify its "practical bearings". In this respect, Peirce argues that a pragmatic clarification should produce a conditional sentence that clarifies a concept by telling how we should act in particular circumstances and according to our desires (168-70). However, there are other formulations of the maxim that focus on how an object (to which the concept at issue is applied) would behave in given circumstances (170-1). Moreover, if we focus on Peirce's examples of pragmatic clarifications instead, we get the impression that what we have to clarify in a concept are the experiences we should 
expect if we attribute that concept to an object, and if we act on the object in a certain way under given circumstances (172, this is the formulation of the maxim that gives more emphasis to the verificationist dimension). In order to find a way out of these ambiguities, Hookway first suggests that these different formulations could simply identify different uses of pragmatic clarifications. Pragmatic clarifications do serve different purposes and they could require different forms according to the purposes they pursue and the contexts in which they are applied (175-6). Keeping this consideration in mind, it is still possible to gain a clearer grasp of how the pragmatist and verificationist elements of the pragmatic maxim could be related in actual clarifications. This is possible when we consider how Peirce applies the pragmatic maxim to particular examples. If we do that, we will see that Peirce seldom tells how we should act in given circumstances. Rather, he identifies how some objects would behave according to general patterns and laws, if we were right in applying the concept at issue to these objects (presumably we could identify verifiable experiential episodes connected to these patterns and laws, my note). There is no explicit mention of how we should act, even though the exposition of these patterns and laws can surely have "practical bearings" (178-9). This does not mean that the pragmatist dimension can be neglected. Pragmatic clarifications focus on general laws and patterns governing the behavior of objects insofar as it would be impossible to identify the different actions we should perform in all possible circumstances and according to all possible desires. Nonetheless, a pragmatic clarification is successful if it gives us the means to evaluate how to act when we are in particular circumstances and have particular desires (179-80).

7 Chapter 11 ("How Peirce Argued for his Pragmatist Maxim") provides another perspective on the pragmatic maxim. Accordingly, it does not focus on the contents of the maxim itself, but on the strategies by means of which Peirce attempted to give a "proof" of the maxim. In particular, Hookway analyses 4 strategies and gives an account of the reasons why Peirce became dissatisfied with them. He first analyses the proof given in 1878 in "How to Make our Ideas Clear", which was based on the identification of beliefs with habits of actions (199-200). Peirce became dissatisfied with this proof as too psychological, and in 1903, in his "Lectures on Pragmatism", attempted a proof based on his theory of inquiry and on his account of abduction (207-12). Hookway then analyses two others proofs based respectively on existential graphs (215-20) and Peirce's semeiotic (220-30). This is probably the most thorough analysis of Peirce's proofs of the pragmatic maxim. It helps us understand why, for Peirce, it was so important to provide such a proof (probably for distinguishing his position from that of other pragmatists). It also explains why Peirce got dissatisfied with previous attempts and it tries to solve some problems in the last proof considered, that is the one based on the notion of "ultimate interpretant" (228 ff.).

8 Hookway's book is also of value for the accurate way in which Peirce's position is compared to the views of other pragmatists and other philosophers. As I already noticed, in chapter two Hookway discusses Peirce's and Rorty's different positions on fallibilism and the aims of inquiry, and he shows how Peirce's account of truth gives us the means to maintain that truth is the aim of inquiry, even though we are fallibilists. Chapter 8 ("Pragmatism and the Given: C. I. Lewis, Quine, and Peirce") is dedicated to assessing Lewis' conception of the given with respect to Peirce's realism. Hookway first undermines some common assumptions about Lewis' epistemology and metaphysics. Accordingly, he shows how the given has not a foundational role in Lewis' 
epistemology, which is coherentist $(152,158)$. Lewis' concept of the given is not essential for his epistemology, but for his metaphysics of knowledge ( $158 \mathrm{ff}$.). In this respect, the given serves a Kantian function and its role "is to provide objects for our knowledge" (158). The given introduces a realist element in Lewis' metaphysics of knowledge (159). Hookway analyses the problems of this position and show how Peirce's account of indexicality gives us the means to account for the independency of reality without facing the problems of Lewis' given (162-3). In chapter 5 ("Normative Logic and Psychology: Peirce's Rejection of Psychology"), Hookway discusses Peirce's insistence that logic should be distinguished from psychology. Peirce's emphasis on this point was motivated by various reasons, but one of these was surely his attempt to distinguish his version of pragmatism from others (84-5). In this respect, Hookway analyses Peirce's reactions to the publication of Studies in Logical Theory, which collected papers by John Dewey and some of his students at the University of Chicago (102-9). In this book Dewey defended the idea that logic should make use of psychology and he identifies logic with the "history of thought". Hookway examines in detail Peirce's criticism of Dewey's psychologism. In Hookway's reading, Peirce's criticisms of Dewey were not based on an endorsement of a pure logic. Rather, Peirce criticized Dewey's logic for its lack of a normative dimension. Resulting from the analyses of actual processes of inquiry, Dewey's logic could only help us understand these processes, but it cannot have any role in the development of new possibilities and methods (in this respect, it would be interesting to study how far Peirce's criticisms influenced the position defended by Dewey in his 1938 book Logic: The Theory of Inquiry). Hookway thus stresses: "Peirce does not divorce logic from the practices of inquiry; rather, he object that Dewey's instrumentalist logic fails to recognize kinds of reflections about logical possibilities which are indispensible to scientific inquiry" (108-9).

Chapter 10 ("Logical Principles and Philosophical Attitudes: Peirce's Response to James's Pragmatism") considers in depth the relationship between Peirce's and James' versions of pragmatism. Various scholars have argued that James' pragmatism was a misunderstanding and popularization of Peirce's views. Others have sustained that James inaugurated a version of pragmatism that had nothing to do with Peirce's position, which was still dominated by traditional concerns (183). Hookway challenges both these points of view. He shows how James did not misunderstand Peirce and he also did not see pragmatism in a totally different way. Rather, he had very different philosophical goals and aims and he developed a version of pragmatism that was apt to attain them. Hookway accordingly stresses: "[i]t is wrong to interpret James as misreading or misunderstanding Peirce's pragmatic maxim. Rather, he seized its fundamental insight about meaning, consequences, and the future, and employed it in the service of a different set of philosophical aims and a contrasting conception of science and its aims" (196). Hookway's reading of Peirce has brought attention to the similarities between some of his views and Kant's account of regulative ideas. Chapter 7 ("A Sort of 'Composite Photograph': Pragmatism, Ideas, and Schematism") draws another comparison between these authors, which focuses on Peirce's notion of "composite photographs" and Kant's account of schematism. Hookway analyses those passages where Peirce uses the concept of a "composite photograph" in order to account for our capacity to apply general concepts to particular objects. In this framework, a "composite photograph" provides a sort of iconic representation of the concept in question that allows us to apply the concept to a particular experience. It is not clear how we could account for this iconic, but general, representation and 
Hookway suggests that it is best read as Peirce's attempt to develop Kant's idea of schematism in a pragmatist context (143 ff.)

10 There would be still much to praise in Hookway's book. It surely presents a collection of essays that are of invaluable help in addressing a variety of problems concerning Peirce, pragmatism, epistemology, metaphysics, etc. As always, the book is particularly of value because it associates detailed and informed historical scholarship with a sharp focus on reconstructing the argument at issue in order to test their relevance for contemporary discussions.

\section{AUTHORS}

\section{GABRIELE GAVA}

Goethe Universität Frankfurt am Main

gabriele.gava[at]gmail.com 